\title{
Comparative Study between Lean Six Sigma and Lean-Agile for Quality Software Requirement
}

\author{
Narishah Mohamed Salleh ${ }^{1}$, Puteri NE Nohuddin ${ }^{2}$ \\ Institute of Visual Informatics \\ National University of Malaysia \\ Bangi 43600 Malaysia
}

\begin{abstract}
Requirement Elicitation is one of the challenging phases in the entire software development life cycle. It is the process of extracting and analyzing the requirements from customers to understand thoroughly of what system needs to be built. Despite all the advances in methodologies and practice approaches, extracting and establishing the right requirements are still part of the research debate. The objective of this paper is to compare the characteristics of two hybrid development approaches; Lean Six Sigma vs. Lean Agile. Most of the comparative studies done by most of the research compared within its relative knowledge such as; Lean vs. Six Sigma, DefineMeasure-Analyze-Improve-Control vs. Design-For-Six-Sigma or Lean vs. Six Sigma vs Lean Six Sigma. Whereas in software industries, the comparative studies were focused on Lean vs. Agile, Agile vs. Waterfall, Lean vs. Kanban vs. Agile, which compared the project size, process cycle time, sequential or iterative process. The following parts of the study is to explore the differences and similarities in principles and practices. The study contributes significantly to the business analysts to systematically address the solutions and actions to ensure continuous improvement in producing quality software requirement.
\end{abstract}

Keywords-Lean Six Sigma; Lean Agile; DMAIC; SCRUM; Requirement Elicitation

\section{INTRODUCTION}

Requirement Engineering is a process of eliciting, analyzing, specifying, validating and managing the requirements to meet end users' objective [1], [2]. The core of requirements engineering is Requirement Elicitation (RE), the process of identifying what the customer needs and understanding the problems to resolve from the software engineering perspective[3], [4]. Without an accurate understanding of what the stakeholders' specification, tendency of projects to be failed is at high degree. It is observed about $12 \%$ to $71 \%$ of the project failure are attributed to poor requirements[5]. Standish report in 2014 revealed that most of significant factors contribute to the software project challenges are Lack of User Input and Incomplete Requirements. Getting the absolute requirements has always been the challenge in the current global and complex business process supply chain. [6], [7] confirmed that a combination of elicitation techniques was required to resolve different types of requirement challenges. Many software methodologies were created to assist team in understanding and providing the optimum solutions; such as Waterfall, Incremental Prototyping, Agile, Lean Software Development (LSD) and hybrid Lean-Agile. All with the same objective to improve quality, to meet customers' needs, reduce software delivery cycle time and reduce the cost of reworks.

The purpose of the research is to investigate similarities and differences of principles and practices between LSS and LA approach. This will assist analysts and researchers to find the benefits, limitations and strengths in software requirement gathering process. The rest of the paper is organized as follows: Section 2 contains characterization and definition of Requirement Elicitation, Lean-Agile and Lean-Six Sigma methods and related work of comparison analysis in the hybrid approach. Section 3 details on discussion and analysis. Section 4 provides the conclusion and summary of the topic.

\section{LITERATURE REVIEW}

\section{A. Requirement Elicitation}

$\mathrm{RE}$ is the process of determining, understanding "what is customer's wants" which is then to be translated into a reality. The process consists of five principles activities [8]. The first principle is the understanding of knowledge domain. The second principle is to identify the main stakeholders in the entire life cycle. The third principle is to analyze the characteristic and behavior of the stakeholders. It is also to evaluate the impact of stakeholders in the project scope. The fourth principle is RE selection techniques. The fifth principle is to extract the requirement from stakeholders or end users. The common RE techniques are Interviews, Discussion, Focus group, Surveys, Observations, Requirements Workshops, Prototyping and others. Researchers confirmed which is impossible to perform stand-alone activity for RE techniques. It is required a combination of $\mathrm{RE}$ techniques to achieve the project goals.

Authors in [7], [9], [10] categorized the elicitation techniques into Traditional, Collaborative, Cognitive and Observational which are summarized in Table I. Each group has different technique to be applied during the requirement elicitation process.

Table I outlines a summary of what RE techniques should be applied at different types of situation. For example, if the end users are well knowledgeable, the interviews and discussions are more than enough to extract the requirement and user specification in full capacity. Despite the category of $\mathrm{RE}$ techniques, there are few practices in the RE process recommended by [11], [12] that were based on value chain analysis: 
- RE preparation - Define objective, scopes and stakeholders, business function scenario and business requirement.

- Non-Functional Requirement and Constrain Availability, reliability and sustainability.

- RE Audition and Negotiations - Control and feedback, evaluate consistency of requirements and describe demand rationality.

- RE Completion - RE process will stop once the requirements met the user's expectation else, the process will be in iterative mode.

Those are the main elements to further elaborate between LSS and LA development model.

\section{B. Lean Six Sigma (LSS)}

Lean Six Sigma (LSS) is a methodology which derived from Six Sigma and Lean Management approach [13]. It is the integrated methodology with a systematic approach to improve organizational performance by removing process wastes and reducing variation through diagnosis and analysis capabilities of Six Sigma. In recent years, more companies have decided to combine Lean and Six Sigma methodologies [14] to improve business process efficiency and to deliver the highest quality to customers. Table II summarized the LSS principles based on previous literatures [15], [16] :

The methodology can be divided into five phases known as DMAIC (Define, Measure, Analyze, Improve and Control) which occurs in sequential order where tollgate review will be done at end of each phases.

Define is the first step to define objective, to identify the stakeholders, to understand and explore customer's requirement. Authors in [20], [21] applied Project Charter template in the research as the outcome at Define Phase which constitute of comprehensive strategy and planning to identify problems, project objective and business goal, scope and boundaries, time of completion and list of stakeholders involved for extrusion process and project costing. Author in [14] recommended few important tools at this phase; problem identification, Voice of Customers (VOC), Drill Down Tree Diagram, High level process map (SIPOC), Critical to Process Qualities and Project Charter.

Measure phase is the second phase which most of the tools are adopted to collect data, to understand current organization which basically to understand "What-Is" scenario data [22]. However, [23], [24] utilized this phase to explore and to investigate the base line of manufacturing process.

The third phase is Analyze which to perform the analysis and to identify the root cause of the problems. It is similar with requirement analysis in traditional Requirement Engineering process. The fourth phase is Improve which is to implement optimized solutions to solve the problem. In requirement engineering, it is known as Design and development phase. The last phase is Control which is to sustain the improved results which is similar concept as Verification and Validation phase in SDLC or Requirement Engineering cycle.

\section{Lean Agile}

Agile was established in 2001 when Agile Manifesto was formulated with the main objective to resolve fluctuating demand or requirement changes in software development. Lean is a management philosophy focused on providing maximum customers' value through end-to-end focus on delivering to customer's needs, efficient work streams, empowered teams and continuous improvement initiatives [25].

\section{TABLE. I. SUMmARY OF ELICITATION TECHNIQUES}

\begin{tabular}{|c|c|c|}
\hline Situational Challenges & Category & Technique \\
\hline $\begin{array}{l}\text { - Stakeholders have deep domain } \\
\text { knowledge. } \\
\text { - End users were cooperative and can } \\
\text { be accessed easily } \\
\text { - System is stereotype }\end{array}$ & Conversational & $\begin{array}{l}\text { Interviews } \\
\text { Discussion }\end{array}$ \\
\hline $\begin{array}{l}\text { - End users have shallow knowledge } \\
\text { and unable to express what they want. } \\
\text { - Business Analyst is new at the } \\
\text { domain. } \\
\text { - End users were not cooperative } \\
\text { - Documents were insufficient and } \\
\text { incomplete }\end{array}$ & $\begin{array}{l}\text { Observational } \\
\text { Synthetic }\end{array}$ & $\begin{array}{l}\text { Protocol } \\
\text { Analysis } \\
\text { Observation } \\
\text { Scenarios } \\
\text { Prototype } \\
\text { JAD/ RAD }\end{array}$ \\
\hline $\begin{array}{l}\text { - Procedures were properly } \\
\text { documented }\end{array}$ & Analytical & $\begin{array}{l}\text { Content } \\
\text { Analysis } \\
\text { Requirement } \\
\text { Reuse }\end{array}$ \\
\hline $\begin{array}{l}\text { - Systems involved with many end } \\
\text { users }\end{array}$ & $\begin{array}{l}\text { Analytical } \\
\text { Observational }\end{array}$ & $\begin{array}{l}\text { Content } \\
\text { Analysis, } \\
\text { Requirement } \\
\text { Reuse }\end{array}$ \\
\hline
\end{tabular}

TABLE. II. PRINCIPLES OF LSS

\begin{tabular}{|l|l|}
\hline Principles & Description \\
\hline Focus on Customers & $\begin{array}{l}\text { It is a principle of creating values to the customer. } \\
\text { Any processes that do not benefit customers will be } \\
\text { considered as a waste [17] }\end{array}$ \\
\hline Value Stream & $\begin{array}{l}\text { Identifying and understanding how the works get } \\
\text { done through value stream mapping is crucial to } \\
\text { visualize the current process before new solution is } \\
\text { proposed }\end{array}$ \\
\hline $\begin{array}{l}\text { Focus on value-add } \\
\text { process }\end{array}$ & $\begin{array}{l}\text { Value Stream analysis, all non-value added tasks } \\
\text { should be eliminated from the process to ensure the } \\
\text { smoothness of the flow [18] }\end{array}$ \\
\hline $\begin{array}{l}\text { Manage, improve and } \\
\text { smooth the process } \\
\text { flow }\end{array}$ & $\begin{array}{l}\text { Lean principle itself is about managing a smooth flow } \\
\text { not only in operations, but also the information and } \\
\text { the material flow where complexity should be } \\
\text { managed and improved. }\end{array}$ \\
\hline $\begin{array}{l}\text { Involve and equip the } \\
\text { people in the process } \\
\text { reduce variation }\end{array}$ & $\begin{array}{l}\text { RSS emphasizes that problems are based on solid } \\
\text { principle where increasing values through respect, } \\
\text { empowerment and growth of learning are vital to } \\
\text { improve collaboration and teamwork. }\end{array}$ \\
\hline $\begin{array}{l}\text { Undertake } \\
\text { improvement activity } \\
\text { in a systematic way } \\
\text { improvement is derived from a structured statistical } \\
\text { analysis [19] }\end{array}$ \\
\hline $\begin{array}{l}\text { LSS followed systematic and proven statistical tools } \\
\text { which is applied to ensure business efficiency and } \\
\text { customer's satisfaction. }\end{array}$ \\
\hline
\end{tabular}


This philosophy was adopted by [26] who considers lean thinking as a "platform upon which to build agile software development practices". Author in [27] argued that although agile and lean have fundamental differences, yet they complement each other by addressing different "components" of systems development. Consequently, software development is interpreting the combination of agile and lean in a different way than in manufacturing. Author in [28] summarized in a research that most of Lean principles have similar objective with agile principle. The focus of related theory in this paper is to explore Lean-Agile principles, methodologies and elicitation process.

Scale Agile Inc developed a framework applied Lean and Agile principles in building large enterprise class software. Scale Agile Framework described nine LA principles which tabulated in Table III. Application of the principles had improved employee involvement, speed up time-to-market, product quality and productivity in Scale Agile Inc.

TABLE. III. PRINCIPLE Of LEAN AgILE

\begin{tabular}{|c|c|}
\hline Principles & Description \\
\hline $\begin{array}{l}\text { Take an economic } \\
\text { view }\end{array}$ & $\begin{array}{l}\text { It is about the principle of business values which to } \\
\text { understand the economic impact of the decision been } \\
\text { made [26] }\end{array}$ \\
\hline $\begin{array}{l}\text { Apply system } \\
\text { thinking }\end{array}$ & $\begin{array}{l}\text { It is a holistic approach which consists of design, } \\
\text { development, deployment and maintenance. It also } \\
\text { the process of optimizing the full value stream with } \\
\text { an integrated end-to-end solution. }\end{array}$ \\
\hline $\begin{array}{l}\text { Assume variability } \\
\text { and preserve options }\end{array}$ & $\begin{array}{l}\text { According to Scale Agile framework (Scaled Agile } \\
\text { Inc.2016), this principle emphasizes of the need to } \\
\text { design multiple options of solutions to ensure speed } \\
\text { of delivery and to avoid hiccup in development. }\end{array}$ \\
\hline $\begin{array}{l}\text { Incremental } \\
\text { Development } \\
\text { Approach with } \\
\text { Integrated Continuous } \\
\text { Improvement }\end{array}$ & $\begin{array}{l}\text { Iterative development is critically important to allow } \\
\text { fast feedback from customers and to reduce risk by } \\
\text { designed and developed solutions in a series of short } \\
\text { iteration [26]. This is similar to Scrum sprint review } \\
\text { [29]. }\end{array}$ \\
\hline $\begin{array}{l}\text { Manage by fact and } \\
\text { reduce variation }\end{array}$ & $\begin{array}{l}\text { LSS emphasizes that problems are based on solid } \\
\text { evidence and baseline data where process } \\
\text { improvement is derived from a structured statistical } \\
\text { analysis. }\end{array}$ \\
\hline $\begin{array}{l}\text { Systematic } \\
\text { Milestones Objective } \\
\text { evaluation }\end{array}$ & $\begin{array}{l}\text { Gates milestones is essential to evaluate the status of } \\
\text { each phase dateline, cost, resources and objectives to } \\
\text { ensure return of investments. }\end{array}$ \\
\hline $\begin{array}{l}\text { Applying Kanban } \\
\text { Principle to improve } \\
\text { visualization, } \\
\text { managing que lengths } \\
\text { and work-in-progress } \\
\text { (WIP) }\end{array}$ & $\begin{array}{l}\text { KANBAN recommends small batches, visualize and } \\
\text { control Work-In-Progress (WIP) and minimize queue } \\
\text { of length to ensure continuous flow, reduces waste } \\
\text { and increase predictability of outcomes [30], [31] . }\end{array}$ \\
\hline $\begin{array}{l}\text { Unlock the intrinsic } \\
\text { motivation of } \\
\text { knowledge workers }\end{array}$ & $\begin{array}{l}\text { It is a principle of creating an environment of mutual } \\
\text { influence, self-direct and respect each other. This is } \\
\text { aligned with Lean Thinking principle and Agile } \\
\text { manifesto where team empowerment is a significant } \\
\text { philosophy to drive for project success }\end{array}$ \\
\hline $\begin{array}{l}\text { Decentralize decision } \\
\text { making }\end{array}$ & $\begin{array}{l}\text { Decentralize decision making is the process of } \\
\text { making a quick decision based on the expertise, } \\
\text { policies and rules to improve cycle time, product } \\
\text { delivery, continuous flow and facilitates faster } \\
\text { feedback. }\end{array}$ \\
\hline
\end{tabular}

Both LSS and LA emphasize "The Principles" as the core values to optimize sustainability in global competitive advantage. Cost reductions, faster time-to-market and highquality products and services are the main pillars in many software developments companies. That is the main reason why the first principle for both LA and LSS is focusing on the customers' values. Author in [32] summarized that any extra steps, processes or features that do not give values to customers are considered wastes which not only impact productivity but also efficiency. Both LA and LSS principles agree that the importance of human involvement in the development cycle where respect, trust and motivation should be restored. LA methodology in software is not specifically a set of method that is designed for Lean-Agile itself. However, it is more on the application of Lean principles into agile processes in different practices for different purpose. Author in [33] had performed a study using hybrid approach which combined Scrum and Kanban method to improve software performance metrics.

One of the significant elements in Lean-agile methodology is communication. Statistic shows that face-to-face communication is the most effective way to convey information which has many advantages. For example, when customers and developers work collectively; if any question or issue or problem arises then it can be solved immediately.

\section{Comparative Study}

There were many studies done to compare Lean and Agile approaches in terms of principles, methodologies, practices and tools to assist the researcher to evaluate and characterize similarities and differences at different perspective. Authors in [32], [23] performed a comparative study between Agile Methodologies towards Heavyweight software development by analyzing the differences between Waterfall and Agile in principles, project size, perspectives and strategies. Author in [34] presented the comparison study of seven agile methodologies to understand the characteristics, advantages and disadvantages. Methodologies of focused were Lean Software Development (LSD), Scrum, Extreme Programming and FDD. The study explored the definition, characteristics and to understand the advantages and disadvantages of agile methods.

The impact of Lean and Agile methods in real application has been performed to evaluate the performance between Lean and Agile methodology. Author in [30] had performed a statistical study to compare SCRUM and Kanban which observed that the Kanban method had performed better than the Scrum method in terms of managing project schedule.

\section{E. Summary of Literature}

Most of the comparative studies done were to compare within the subject itself, for example; Lean vs. Agile, LeanAgile vs. heavyweight methods, Lean vs. Six Sigma, and LeanSigma vs. Six Sigma or Lean-Sigma vs. Total Quality Management methods. Most of agile methodologies research is done from software related domain while Lean-Sigma is focused on manufacturing product and process cycles. There was no analysis done to compare between hybrid methodologies such as Lean-Sigma vs. Lean-Agile at requirement gathering process for software requirement. Characterization analysis of principles and methodologies will 
be much help for analysts and researchers to explore the differences or similarities. In this research, a comparison study of two hybrid methodologies, LA and LSS, was performed to characterize principles and methodologies in relation to $\mathrm{RE}$ process. Understanding main differences and commonalities between the hybrid technologies will speed up development process, project cycle time and cost.

\section{DiSCUSSION AND ANALYSIS}

In this section, the similarities and differences of the principles, methodologies and practices between LSS and LA are discussed and analyzed. The principles will be analyzed and characterized based on the relationship of RE which are; Understanding Knowledge Domain, Identify Stakeholders, Analyze stakeholders' characteristics and behavior, RE Selection techniques, Documentation and Refinement.

\section{A. Comparative Analysis of Principles}

[10],[25] in the book title as "Lean Integration", confirmed that lean concept is embedded in agile which many of the principles are aligned to each other. Comparative analysis for this research is to evaluate any similarities and differences between LSS and LA in relations to RE principles. Table IV listed the comparison of principles between LA, LSS and Requirement Elicitation;

TABLE. IV. COMPARISON BY PRINCIPLES

\begin{tabular}{|c|c|c|}
\hline Lean Agile & $L S S$ & $\boldsymbol{R E}$ \\
\hline $\begin{array}{l}\text { - Take an economic } \\
\text { view }\end{array}$ & - Focus on Customer & $\begin{array}{l}\text { - Understand what } \\
\text { customer wants } \\
\text { - Identify } \\
\text { stakeholder }\end{array}$ \\
\hline $\begin{array}{l}\text { - Apply system } \\
\text { thinking }\end{array}$ & $\begin{array}{l}\text { - Identify and } \\
\text { understand how the } \\
\text { works were done }\end{array}$ & $\begin{array}{l}\text { - Stakeholder } \\
\text { analysis } \\
\text { - Elicitation } \\
\text { techniques } \\
\text { selection }\end{array}$ \\
\hline $\begin{array}{l}\text { - Incremental } \\
\text { Development } \\
\text { Approach with } \\
\text { Integrated Continuous } \\
\text { Improvement }\end{array}$ & $\begin{array}{l}\text { - Sequential and } \\
\text { Continuous } \\
\text { Improvement } \\
\text { - Integrated } \\
\text { Management approach }\end{array}$ & $\begin{array}{l}\text { - Iterative elicitation } \\
\text { process }\end{array}$ \\
\hline $\begin{array}{l}\text { Visualize and limit } \\
\text { WIP, reduce batch } \\
\text { size and manage } \\
\text { queue lengths }\end{array}$ & $\begin{array}{l}\text { - Streamlining and Lean } \\
\text { process flow }\end{array}$ & \\
\hline $\begin{array}{l}\text { - Assume variability, } \\
\text { preserve options }\end{array}$ & $\begin{array}{l}\text { - Remove non-value } \\
\text { add tasks } \\
\text { - Managed by fact and } \\
\text { reduced variations }\end{array}$ & \\
\hline $\begin{array}{l}\text { - Base milestones on } \\
\text { objective evaluation } \\
\text { working system } \\
\text { - Apply cadence, } \\
\text { synchronize with } \\
\text { cross-domain } \\
\text { planning }\end{array}$ & $\begin{array}{l}\text { - Undertake } \\
\text { improvement activities } \\
\text { in systematic ways }\end{array}$ & \\
\hline $\begin{array}{l}\text { - Unravel the } \\
\text { underlying motivation } \\
\text { of knowledge workers }\end{array}$ & $\begin{array}{l}\text { - Involve and equip the } \\
\text { people in the process }\end{array}$ & \\
\hline
\end{tabular}

Table IV summarizes the relationship of LSS vs LA from RE principles perspective. First RE principle is to understand the business functions or domain knowledge of the specific area. LSS and LA main elaborate this principle by concentrates on the customer and economic values respectively. Customer values is translated into economic gain that is direct correlation towards understanding the domain of knowledge. For example, Insurance process flow, Financial Supply Chain Management, Manufacturing Planning and Scheduling, Financial Payment and Billing process, Human Resources, Engineering and others. Understanding business process is related to process owners. The second and third principles for RE are to identify stakeholders and stakeholder analysis.

The second and third principles for RE are to identify stakeholders and stakeholder analysis. Stakeholders are the primary sources of the information which known as the Subject Matter Expert for specific domain. LSS and LA principles cover this principle related to Customer Focus and Economic View. That is why identify who are the stakeholders are vital to both LSS and LA principles to ensure knowledge extracting process would be done efficiently. For stakeholder analysis, LSS is exploring and investigating how the entire process is currently done through high level process map. While LA is applying systems thinking that consists of comprehensive approach with several aspects in software development. Selecting elicitation techniques based on situational background has been discussed in Table I which is correlated with the result of stakeholder analysis.

The fourth RE principle is quite difficult to adopt because it requires a high technical and experienced team to discover information from the affected users. It is highly dependent on the knowledge of its relative domain. In LSS, principle of stakeholder analysis is elaborated detail with principle of "Focus to Customer". Any process that do not added values at customer process, such feature should have not been developed. Non- valued added activities can be identified from the value stream map which can be extracted from Voice of Process and Voice of Business. The Fifth RE principle is documentation and refinement knowledge discoveries which correlated with Incremental Development and Continuous Improvement Approach principle in LA. Incremental development is the process where respective requirements are captured and stored in product backlog. Reviewing each requirement at every sprint with continuous enhancement is considered critical to optimize the process. This principle also known as adaptive approach where LA focuses towards solution with a series of short iterations to gain fast feedback from customers that translated to minimize the risks [35].

Iterative principle is in the opposite with LSS which emphasizes problem solving management approach known as data and facts driven. Problems is defined based on actual data through comprehensive statistical analysis and lean applications before proposed solutions are provided. Refinement discoveries is aligned with iterative which the process will go through cycle of activities where it will end once the requirements are confirmed by users. But LSS is practically ensure a smooth and uninterrupted process flow and focuses only on customers' values. Six Sigma particularly stresses "critical to quality" processes or operations and 
reduces costs by reducing variability. Another key principle is to empower the organization for LSS and employee's motivation for LA. Both LSS and LA enforce the important values of human capital development to maximize profitability and sustainability. These are the important elements that were expanded from RE principles. Most of LA principles elaborate the important roles from development.

Overall, the principles defined for LSS and LA are completing each other with the goal to achieve similar customer's objective. Technically, in software development, applying LSS or LA with respective of its underlying foundation of knowledge did not interrupt the objectives of the projects. In fact, both principle of knowledge for both LSS and LA are driven towards customer's goal and objectives.

\section{B. Comparative Analysis of LSS and LA towards Requirement Process}

This section of comparative analysis is to evaluate the practices and tools applied either in LA or LSS based on DMAIC and SCRUM. The focus phase is related to "Definition" for LA and "Define and Measure" for LSS. Main elements to study are regarding the requirement known as; Requirement Preparation, Requirement Representation, Requirement Refinement and Requirement Confirmation. This section analyzed the practices between LSS and LA with regards to requirement elicitation process.

Requirement Preparation is the initial phase for analysts and team to start the planning and preparation activities. LSS applied Project Charter as the main guidance which represents all the key information to start on the project such as objectives, identify stakeholders, knowledge domain, project scope and limitations, estimate cost and others. Table V summarized the findings:

TABLE. V. SUMMARY BY PROCESS

\begin{tabular}{|c|c|c|}
\hline $\begin{array}{l}\text { Requirement } \\
\text { Elements }\end{array}$ & Definition Phase (LA) & $\begin{array}{l}\text { Define and Measure Phase } \\
\text { (LSS) }\end{array}$ \\
\hline $\begin{array}{l}\text { - Requirement } \\
\text { Preparation }\end{array}$ & $\begin{array}{l}\text { - Planning meeting } \\
\text { with stakeholders } \\
\text { - Kick Off Meeting to } \\
\text { define structure }\end{array}$ & $\begin{array}{l}\text { - Prepare Project Charter } \\
\text { Template } \\
\text { - Elaborate Project Charter } \\
\text { for Objective, } \\
\text { Stakeholders and key } \\
\text { metrics }\end{array}$ \\
\hline $\begin{array}{l}\text { - Requirement } \\
\text { Specification }\end{array}$ & $\begin{array}{l}\text { - Define User Stories } \\
\text { - Product Backlogs }\end{array}$ & $\begin{array}{l}\text { - } \text { SIPOC } \\
\text { - Voice of Customers } \\
\text { (VOC) } \\
\text { - Voice of Process (VOP) } \\
\text { - CTQ metrics }\end{array}$ \\
\hline $\begin{array}{l}\text { - Requirement } \\
\text { Refinement }\end{array}$ & $\begin{array}{l}\text { - Face to Face } \\
\text { Communication } \\
\text { - Frequent Meetings } \\
\text { - On Site Meeting } \\
\text { - Product backlogs } \\
\text { update }\end{array}$ & $\begin{array}{l}\text { - Enforce "What-Is" } \\
\text { through process mapping } \\
\text { (Swimlane Diagram) } \\
\text { - Transfer Functions } \\
\text { - Lean Waste Analysis }\end{array}$ \\
\hline $\begin{array}{l}\text { - Requirement } \\
\text { Confirmation }\end{array}$ & $\begin{array}{l}\text { - Prototyping } \\
\text { - Adaptive process }\end{array}$ & $\begin{array}{l}\text { - Process Performance } \\
\text { Analysis } \\
\text { - Process Mapping } \\
\text { Optimization } \\
\text { - Drill Down Tree } \\
\text { Diagram }\end{array}$ \\
\hline
\end{tabular}

Table V showed that LA main tasks are planning meeting with stakeholders to understand the objective, to prepare all the relevant questions to the respective team. Kick Off meeting is the recommended tool [36] to define the structure with the customers. It is highly depending on the competent skills of analysts to ask the right questions to the customers. At this phase, the assumption is customers know what is needed.

Requirement Specification phase is the process to identify the systems that needs to be built. LA best practices focuses on the involvement of users such as user stories and product backlogs. User stories are the notation of expressing the requirements which commonly used in Agile development. It is practical with the assumption that users able to articulate the situations that currently done. Product backlogs are the inputs from all the stakeholders which can be categorized as Functional and Non-Functional Requirements.

While LSS recommended VOC or QFD to understand and to discover the requirement specifications. VOC is the comprehensive tools to discover the implicit and explicit requirements from end users. Not only that, SIPOC is used to understand the overview of the process in the entire supply chain [17], [37].

Daily meeting and product backlog updates at each sprint are common practice done in LA for requirement refinement purpose. Product backlog is also known as checklists thus both parties are on the mutual agreement of the subject domain. In fact, it is also act as a communication medium among developers and Scrum Masters for effective tracking purpose [38]. However, LSS is applying detail process mapping such as swim lane diagram to understand tasks and detail task. Swim lane diagram helps analysts to visualize the interaction of the processes and the roles for each stakeholder within that domain of supply chain [39], [40].

Requirement confirmation or documentation is the phase where proper documentation is signed off to confirm on the policy, rules and agreement. At this phase, LA approach utilized early prototyping at each iterations process to gather fast feedback. Once the preferred options are selected, the detailed requirement is explored using storyboards, situational scenarios and prototyping techniques. Again, an iterative approach is used at this stage in order to develop a final operational prototype. From "What-Is" process mapping, team able to propose "To-Be" solutions, either using automation through script development to optimize value essentials process or to explore knowledge base rules to refine the specification. The next phases in LSS which known as Analyze, Improve and Control will elaborate further of the validation process.

The main difference in the two methods are the practices applied at different phases of the cycle where LSS applies many different tools to acquire and to represent the requirements, while LA focuses more on the effective communications among the stakeholders at every sprint review. Prototyping is a technique that is quite often mentioned in the LA approach compared to LSS especially at the end of the sprint review. This is due to the principle of LA itself where the development projects deliver its functionality incrementally at every phase. It is due to the change of 
requirement whenever there is new knowledge observed. Incremental delivery is a process where developer provides a solution with added functionality based on the feedback of every sprint review. But LSS is more on the structure and systematic management problem approach where systematic tools and practices are in place to understand and visualize current process before solutions were proposed. The DMAIC framework could be utilized not only at software solution and development projects but also at the feasibility study phase where fuzzy problems occurred.

\section{CONCLUSION}

In Agile perspective, every aspects of development, requirements need to be revisited to ensure conformance. This principle empowers team to continuously re-plan the product release to be more comparative and flexible with current economic uncertainty. Lean Six Sigma (LSS) is becoming popular in almost all organizations from many different industries globally. It is a management philosophy which provides a world class business strategy that requires an organizational change, leadership, promotes successful teamwork, in systematic and structured approach. The entire methodology is the explorative process from unknown to a clear defines solutions because it is data and facts driven. Thus, LSS is very beneficial to new analysts or experienced researchers to discover the real problems in the organization.

Lean and Agile are two different origins but some of the practices can be combined to face volatile demand in customer responsiveness. Producing a software system that fulfills $100 \%$ of customers' needs is no way possible. However, there is a standard methodology and practices that would resolve the challenges at a very comparative cost. Lean-Agile focuses on customer satisfaction, flexibility and rapidly embrace changes at most effective economical approach to improve business or product value. However, Lean-Agile is highly depending on the stakeholders as the main input which contributes to high risk of uncertainty. Though LA is very adaptive and flexible in managing frequent requirement changes, the chances of cost over-run is at high stake.

If analyzing based on methods and practices, LSS is very promising due to its systematic and structured guidelines. Each phase, there are proven recommended tools to be utilized by analysts or researchers to move forward. LSS typical framework, the process is well defined from Define stage to Implementation and Control stage where researchers could forecast the project planning efficiently. The recommended tools applied at each phase have its own steps and procedure to guide researcher to refine the requirement process. DMAIC methodology is used to incorporate Six Sigma and Lean tools to improve processes by systematically reducing the variations, while creating even flow with the objective to delight customers by focusing on quality and speed.

Future research might extend the work to perform a case study between LA and LSS at specific phases; for example: requirement development phase. This is to confirm how LSS and LA difference in practicality.

\section{REFERENCES}

[1] L. R. Wong, D. S. Mauricio, and G. D. Rodriguez, "A systematic literature review about software requirements elicitation. Journal of Engineering Science and Technology," J. Eng. Sci. Technol., vol. 12, no. 2, pp. 296-317, 2017.

[2] E. Schön, D. Winter, and M. J. Escalona, "Agile Processes in Software Engineering and Extreme Programming," vol. 283, pp. 37-51, 2017.

[3] T. Iqbal, "Requirement Elicitation Technique : - A Review Paper," Int. J. Comput. Math. Sci., vol. 3, no. 9, pp. 1-6, 2014.

[4] V. Singh, S. Sankhwar, and D. Pandey, "A framework for requirement elicitation," no. February, 2014.

[5] B. Davey and K. R. Parker, "Requirements elicitation problems: a literature analysis," Issues Informing Sci. Inf. Technol., vol. 12, pp. 7182,2015 .

[6] F. A. and R. Razali, "A Practical Guide to Requirements Elicitation Techniques Selection - An Empirical Study," Middle-East J. Sci. Res., vol. 11, no. 8, p. 9, 2012.

[7] S. Tiwari and S. S. Rathore, "A Methodology for the Selection of Requirement Elicitation Techniques," 2017.

[8] L. Bormane, J. Gržibovska, S. Bērziša, and J. Grabis, "Impact of Requirements Elicitation Processes on Success of Information System Development Projects,” Inf. Technol. Manag. Sci., vol. 19, no. 1, 2016.

[9] S. Tiwari, S. S. Rathore, and A. Gupta, "Selecting requirement elicitation techniques for software projects," in 2012 CSI Sixth International Conference on Software Engineering (CONSEG), 2012, pp. 1-10.

[10] R. Egas, "Requirements elicitation, which method in which situation?," Open Univ. Netherlands, p. 70, 2015.

[11] N. Jacob and H. Dekkers, "Requirements Elicitation Technique: Improving the Interview Technique," Univ. Amsterdam, no. 10629505, pp. 1-26, 2015.

[12] H. Liao, "Requirement Elicitation Based on Value Chain Analysis," J. Theor. Appl. Inf. ..., vol. 50, no. 2, 2013.

[13] M. P. J. Pepper and T. A. Spedding, "The evolution of lean Six Sigma," Int. J. Qual. Reliab. Manag., vol. 27, no. 2, pp. 138-155, 2010.

[14] A. Tenera and L. C. Pinto, "A Lean Six Sigma (LSS) Project Management Improvement Model," Procedia - Soc. Behav. Sci., vol. 119, pp. 912-920, 2014.

[15] A. Mirela and C. Munteanu, "Comparative Analysis between Lean, Six Sigma and Lean Six Sigma Concepts," J. Manag. Econ., vol. 2, no. 1, pp. 78-89, 2017.

[16] R. Yousef and T. Almarabeh, "An enhanced requirements elicitation framework based on business process models," vol. 10, no. 1, pp. 279286, 2015.

[17] J. Antony, D. Setijono, and J. J. Dahlgaard, "Total Quality Management \& Business Excellence Lean Six Sigma and Innovation - an exploratory study among UK organisations," vol. 27, no. December, pp. 37-41, 2014.

[18] R. Panat*, V. Dimitrova, T. Selvy Selvamuniandy, K. Ishiko, and D. Sun, "The application of Lean Six Sigma to the configuration control in Intel's manufacturing R\&amp;D environment," Int. J. Lean Six Sigma, vol. 5, no. 4, pp. 444-459, 2014.

[19] T. Reijns, "The advantages and limitations of Lean Six Sigma in process ( re ) design," no. June, p. 32, 2010.

[20] S. Kelly, "Towards an evolutionary framework for agile requirements elicitation," in Proceedings of the 2nd ACM SIGCHI symposium on Engineering interactive computing systems - EICS '10, 2010, p. 349.

[21] W. Behutiye, P. Karhapää, D. Costal, M. Oivo, and X. Franch, "Nonfunctional requirements documentation in agile software development: Challenges and solution proposal," Lect. Notes Comput. Sci. (including Subser. Lect. Notes Artif. Intell. Lect. Notes Bioinformatics), vol. 10611 LNCS, pp. 515-522, 2017.

[22] X. Q. Xu, C. Huang, and H. Lu, "Application of Lean Six Sigma Methodology in Software Continuous Integration," Key Eng. Mater., vol. 693, pp. 1893-1898, 2016. 
[23] J. A. Garza-Reyes, M. Al-Balushi, J. Antony, and V. Kumar, “A Lean Six Sigma framework for the reduction of ship loading commercial time in the iron ore pelletising industry," Prod. Plan. Control, vol. 27, no. 13, pp. 1092-1111, 2016

[24] A. C. Tonini, M. De Mesquita Spínola, and F. J. B. Laurindo, "Six sigma and software development process: DMAIC improvements," Portl. Int. Conf. Manag. Eng. Technol., vol. 6, no. c, pp. 2815-2823, 2006.

[25] R. Suomela, "Using Lean Principles to Improve Software Development Practices in a Large-Scale Software Intensive Company," 2015.

[26] M. Poppendieck and T. Poppendieck, Lean Software Development: An Agile Toolkit. 2003.

[27] E. Bjarnason, K. Wnuk, and B. Regnell, "A case study on benefits and side-effects of agile practices in large-scale requirements engineering," Proc. 1st Work. Agil. Requir. Eng. - AREW '11, pp. 1-5, 2011.

[28] N. Schmidt and C. Meures, "Mind the Gap': An Analysis of Communication in Agile Global Outsourced Software Development Projects," 2016 49th Hawaii Int. Conf. Syst. Sci., pp. 501-510, 2016.

[29] K. Petersen and C. Wohlin, "Measuring the flow in lean software development," Software-Practice Exp., vol. 41, no. 9, SI, pp. 975-996, 2011.

[30] H. Lei, F. Ganjeizadeh, P. K. Jayachandran, and P. Ozcan, "A statistical analysis of the effects of Scrum and Kanban on software development projects," Robot. Comput. Integr. Manuf., pp. 1-9, 2015.

[31] E. Corona, F. Eros, and P. Diee, "A Review of Lean-Kanban Approaches in the Software Development," vol. 10, no. 1, pp. 1-13, 2013.

[32] A. K. R. Pillai, A. K. Pundir, and L. Ganapathy, "Implementing Integrated lean six sigma for software development: A flexibility framework for managing the continuity: Change dichotomy," Glob. J. Flex. Syst. Manag., vol. 13, no. 2, pp. 107-116, 2012.

S. Khan1, A. B. Dulloo2, and M. Verma3, "Systematic Review of Requirement Elicitation Techniques," Int. J. Inf. Comput. Technol., vol. 4, no. 2, pp. 133-138, 2014.

[33] S. Merzouk, S. Elhadi, H. Ennaji, A. Marzak, and N. Sael, "A Comparative Study of Agile Methods: Towards a New Model-based Method," vol. 9, no. 4, pp. 121-128.

[34] B. Kola, "Thinking Lean in Agile Software Development Projects," 2014.

[35] R. Vallon, L. Wenzel, M. E. Brüggemann, and T. Grechenig, “An Agile and Lean Process Model for Mobile App Development: Case Study into Austrian Industry," J. Softw., vol. 10, no. 11, pp. 1245-1264, 2015.

[36] S. M. Saad and M. Khamkham, "Development of Lean Six-Sigma Conceptual Implementation Model for Manufacturing Organisations," Adv. Manuf. Technol. Xxx, vol. 3, pp. 497-502, 2016.

[37] N. Ramadan and S. Megahed, "Requirements Engineering in Scrum Framework," Int. J. Comput. Appl., vol. 149, no. 8, pp. 24-29, 2016.

[38] M. L. George et al., The Lean Six Sigma Pocket Toolbook: A Quick Reference Guide to Nearly 100 Tools for Improving Process Quality, Speed, and Complexity The Lean Six Sigma Pocket Toolbook: A Quick Reference Guide to Nearly 100 Tools for Improving Process Quality, Speed, and. McGraw-Hill, 2005.

[39] T. Bortolotti, P. Romano, and B. Nicoletti, "Lean first, then automate: An integrated model for process improvement in pure service-providing companies," IFIP Adv. Inf. Commun. Technol., vol. 338 AICT, pp. 579$586,2010$. 